\title{
ELECTROPHORESIS OF SERA IN MULTIPLE SCLEROSIS AND OTHER NEUROLOGICAL DISEASES
}

\author{
BY
}

\section{ELIZABETH M. PRESS}

From the S. A. Courtauld Institute of Biochemistry, Middlesex Hospital, London

It is a well established fact that in a large percentage of cases the cerebrospinal fluid gamma globulin is increased in multiple sclerosis but the serum gamma globulin is not raised. Changes in albumin and alpha and beta globulin concentrations have been reported by Bernsohn and Cochrane (1954) and by Volk, Saifer, Rabiner, and Oreskes (1955).

In the present investigations a comparison has been made of the serum proteins of 11 normal subjects, 28 patients with multiple sclerosis, and nine patients having other organic disease of the nervous system.

\section{Method}

Electrophoresis was performed on an Antweiler micro apparatus, using veronal buffer $p \mathrm{H} 8 \cdot 6, \mathrm{I}=0 \cdot 1$, as described by Geissen, Schuler, and Schuster (1950). The normal controls ranged in age from 21 to 40 years, and the multiple sclerosis patients from 23 to 53 years, 13 being under 35 years. The duration of the disease was from a month to 15 years, and the average duration four and a half years. In 22 of the cases the disease was active.

\section{Results}

The mean values and standard deviations for the protein fractions in normal sera and sera of patients with multiple sclerosis are given in Table I. The

TABLE I

ELECTROPHORETIC ANALYSIS OF NORMAL SERA AND OF SERA IN MULTIPLE SCLEROSIS

\begin{tabular}{|c|c|c|c|c|c|c|c|c|}
\hline & \multirow{2}{*}{\multicolumn{2}{|c|}{ Albumin }} & \multicolumn{6}{|c|}{ Globulin } \\
\hline & & & \multicolumn{2}{|c|}{ Alpha $_{2}$} & \multicolumn{2}{|c|}{ Beta } & \multicolumn{2}{|c|}{ Gamma } \\
\hline & $\underset{\%}{\text { Mean }}$ & S.D. & $\underset{\%}{\text { Mean }}$ & S.D. & $\underset{\%}{\text { Mean }}$ & S.D. & $\underset{\%}{\text { Mean }}$ & S.D. \\
\hline Normals (11) & 63.4 & $2 \cdot 7$ & $7 \cdot 7$ & $1 \cdot 5$ & $13 \cdot 0$ & $2 \cdot 6$ & 15.9 & $2 \cdot 7$ \\
\hline $\begin{array}{l}\text { Multiple } \\
\text { sclerosis (28) }\end{array}$ & $58 \cdot 2$ & $3 \cdot 6$ & $11 \cdot 0$ & $2 \cdot 4$ & 13.9 & $2 \cdot 7$ & $16 \cdot 9$ & $2 \cdot 8$ \\
\hline
\end{tabular}

normal values are similar to those published by other workers (Bierring and Nielsen, 1952). Statistical analysis shows that for the multiple sclerosis patients the mean value of albumin concentration is significantly decreased and the alpha $a_{2}$ globuli勇 significantly increased $(P<0.001$ in both cases? The mean concentrations for beta and gammfa globulin, however, are not significantly different from the normal means ( $P=\mathbf{0 . 3}$ in each case).

In order to determine whether there was anfy relationship between the concentration of serumalpha $_{2}$ globulin and the duration of the disease of the age of the patient, the multiple sclerosis patients were divided into two groups according to whether the duration was less than two years or more, agnid also according to age, over or under 35 yenis (Tables II and III). In both instances the differereses

TABLE II

RELATIONSHIP BETWEEN ALPHA, GLOBULINO ฮ̄ CONCENTRATION IN SERA IN MULTIPLE SCLEROS出 AND DURATION OF DISEASE

\begin{tabular}{l|c|c|c|}
\hline Duration of Disease & $\begin{array}{c}\text { Mean Concentration } \\
\% \text { Total Protein }\end{array}$ & $\begin{array}{c}\text { Standard } \\
\text { Deviation }\end{array}$ & $\begin{array}{c}\text { No } \\
\text { Cases }\end{array}$ \\
\hline Less than 2 years & $11 \cdot 3$ & 2.2 & 11 \\
More than 2 years & 10.9 & 2.6 & 17 \\
\hline
\end{tabular}

TABLE III

RELATIONSHIP BETWEEN ALPHA, GLOBULIN CONCENTRATION IN SERA IN MULTIPLE SCLEROSIS AND AGE OF PATIENTS

\begin{tabular}{ll|c|c|c}
\hline \multicolumn{1}{|c|}{ Age of Patient } & $\begin{array}{c}\text { Mean Concentration } \\
\% \text { Total Protein }\end{array}$ & $\begin{array}{c}\text { Standard } \\
\text { Deviation }\end{array}$ & $\begin{array}{c}\text { No. of } \\
\text { Cases }\end{array}$ \\
\cline { 1 - 2 } Under 35 years & $\ldots$ & $10 \cdot 8$ & 2.4 & 13 \\
Over 35 years & $\ldots$ & $11 \cdot 2$ & 2.5 & 15 \\
\hline
\end{tabular}

in the mean values of alpha $a_{2}$ globulin were not significant $(P=0 \cdot 5)$. The Lange gold curve was positive in the cerebrospinal fluid of 13 of the patients; the mean values of serum alpha ${ }_{2}$ globulin of patients having positive and negative Lange gol\$ reactions are shown in Table IV. There is no significant difference between these means $(P=0.8)$.

A comparison between the normals and the group of nine cases of organic disease of the nervous system (Table V) shows that the means of albumin alpha $a_{2}$, and beta globulins are significantly different 
TABLE IV

RELATIONSHIP BETWEEN ALPHA, GLOBULIN CONCENTRATION IN SERA IN MULTIPLE SCLEROSIS AND CEREBROSPINAL FLUID LANGE GOLD TEST

\begin{tabular}{|c|c|c|c|c|c|}
\hline \multicolumn{3}{|c|}{ Lange Gold Test } & $\begin{array}{l}\text { Mean Concentration } \\
\% \text { Total Protein }\end{array}$ & $\begin{array}{l}\text { Standard } \\
\text { Deviation }\end{array}$ & $\begin{array}{l}\text { No. of } \\
\text { Cases }\end{array}$ \\
\hline $\begin{array}{l}\text { Positive } \\
\text { Negative }\end{array}$ & $\begin{array}{l}\cdots \\
\cdots\end{array}$ & $\cdots$ & $\begin{array}{l}11 \cdot 1 \\
10 \cdot 9\end{array}$ & $\begin{array}{l}2 \cdot 7 \\
2 \cdot 2\end{array}$ & $\begin{array}{l}13 \\
15\end{array}$ \\
\hline
\end{tabular}

TABLE $\mathrm{V}$

ELECTROPHORETIC ANALYSIS OF NEUROLOGICAL SERA

\begin{tabular}{|c|c|c|c|c|}
\hline \multirow{2}{*}{ Disease } & \multirow[b]{2}{*}{$\underset{(\%)}{\text { Albumin }}$} & \multicolumn{3}{|c|}{ Globulin } \\
\hline & & $\underset{(\%)}{\text { Alpha }_{2}}$ & $\begin{array}{r}\text { Beta } \\
(\%)\end{array}$ & $\underset{(\%)}{\operatorname{Gamma}}$ \\
\hline $\begin{array}{l}\text { Tabes dorsalis } \\
\text { Chronic peripheral neuro- } \\
\text { pathy }\end{array}$ & $\begin{array}{l}59 \\
52\end{array}$ & $\begin{array}{l}12 \\
14\end{array}$ & $\begin{array}{l}13 \\
19\end{array}$ & $\begin{array}{l}16 \\
15\end{array}$ \\
\hline $\begin{array}{l}\text { Chronic encephalomyelo- } \\
\text { radiculitis (inactive) }\end{array}$ & 64 & 12 & 15 & 9 \\
\hline $\begin{array}{l}\text { Polyneuritis } \quad \cdots \\
\text { Intracranial aneurysm-- } \\
\text { ankylosing spondylitis }\end{array}$ & $\begin{array}{l}56 \\
53\end{array}$ & $\begin{array}{l}16 \\
13\end{array}$ & $\begin{array}{l}13 \\
19\end{array}$ & $\begin{array}{l}15 \\
15\end{array}$ \\
\hline $\begin{array}{l}\text { Haematomyelia } \ldots \\
\text { Brain-stem vascular lesion } \\
\text { Cervical spondylosis-pneu- } \\
\text { monia-angina pectoris }\end{array}$ & $\begin{array}{l}57 \\
55 \\
54\end{array}$ & $\begin{array}{l}15 \\
10 \\
17\end{array}$ & $\begin{array}{l}15 \\
15 \\
18\end{array}$ & $\begin{array}{l}13 \\
20 \\
11\end{array}$ \\
\hline $\begin{array}{l}\text { Paraplegia-diabetes melli- } \\
\text { tus-arteriosclerosis }\end{array}$ & 50 & 12 & 22 & 16 \\
\hline $\begin{array}{r}\text { Mean.. } \\
\text { Standard deviation.. }\end{array}$ & $\begin{array}{r}55 \cdot 3 \\
5 \cdot 0\end{array}$ & $\begin{array}{r}13 \cdot 0 \\
2 \cdot 5\end{array}$ & $\begin{array}{r}16 \cdot 5 \\
2 \cdot 7\end{array}$ & $\begin{array}{r}15 \cdot 2 \\
3 \cdot 3\end{array}$ \\
\hline $\begin{array}{cc}\text { Normal Series } & \text { Mean.. } \\
\text { Standard deviation.. }\end{array}$ & $\begin{array}{r}63 \cdot 4 \\
2 \cdot 7\end{array}$ & $\begin{array}{l}7 \cdot 7 \\
1 \cdot 5\end{array}$ & $\begin{array}{r}13 \cdot 0 \\
2.6\end{array}$ & $\begin{array}{r}15 \cdot 9 \\
2 \cdot 7\end{array}$ \\
\hline
\end{tabular}

from the normal means $(\mathrm{P}<0.001)$. The gamma globulin concentration is not significantly different from the normal value $(P=0.5)$.

\section{Discussion}

The disease was active in 22 of the multiple sclerosis patients, but only 12 of these had raised alpha $_{2}$ globulin concentration, i.e., more than two standard deviations above the normal mean. Also, of the six patients in whom the disease was inactive, four had increased alpha $_{2}$ globulin concentration. There is, therefore, no correlation between the alpha $_{2}$ globulin concentration and the activity or duration of the disease, the age of the patient, or the results of the Lange gold reaction on the cerebrospinal fluid.

It is interesting to compare these results with those reported by Bernsohn and Cochrane (1954), who found the mean values of albumin decreased and alpha $_{2}$ increased in a series of 27 cases of multiple sclerosis. The duration of the disease is not stated, but the age of the patients ranged from 27 to 41 years. Also Volk and others (1955) reported a significant difference in the mean values of albumin, alpha $_{2}$, and beta globulin in a series of 43 cases of multiple sclerosis. In this series, however, the average duration of the disease was 18 years.

Increased alpha ${ }_{2}$ globulin concentration has been reported in other pathological conditions. Longsworth, Shedlovsky, and MacInnes (1939) found increases in nephrosis and fevers, while Flynn (1954) reported increases in cases of high fever, tissue destruction, nephrotic syndrome, collagen disease, and malignant disease. The 28 patients with multiple sclerosis studied were all in-patients, and with one exception none were febrile or had other complications while in hospital. The only cases of infection were four patients with chronic tonsillitis and three with infected teeth. In each case electrophoresis was performed before the tonsillectomy or dental extraction. One patient had a history of recurrent thrombophlebitis and developed an attack at the site of the venepuncture carried out to obtain the specimen of blood for this study. It is evident, therefore, that the increased alpha $a_{2}$ globulin and decreased albumin concentrations found in the sera of some of the multiple sclerosis patients are not due to fever, urinary, or other complications. These changes are not, however, specific for multiple sclerosis as they occur in other neurological diseases.

\section{Summary}

An increase in serum alpha globulin and a decrease in albumin concentrations can occur in the early and later stages of multiple sclerosis. These changes cannot be correlated with the activity or duration of the disease, the age of the patient, or the Lange colloidal gold reaction on the cerebrospinal fluid and they are not specific for multiple sclerosis.

The author wishes to thank Dr. D. McAlpine for supplying the sera and the clinical data, and Professor Sir Charles Dodds and Dr. D. McAlpine for their advice and encouragement.

\section{REFERENCES}

Bernsohn, J., and Cochrane, L. S. G. (1954). Proc. Soc. exp. Biol. $(N . Y), 86,540$.

Bierring, E., and Nielsen, E. (1952). Scand. J. clin. Lab. Invest. 4, 281.

Flynn, F. V. (1954). Proc. roy. Soc. Med., 47, 827

Geissen, W., Schuler, B., and Schuster, H. F. (1950). Klin. Wschr. 28, 751 .

Longsworth, L. G., Shedlovsky, T., and MacInnes, D. A. (1939). J. exp. Med., 70, 399.

Volk, B. W., Saifer, A., Rabiner, A. M., and Oreskes, I. (1955). A.M.A. Arch. Neurol. Psychiat. 73, 66. 